\title{
Goroho (Musa acuminafe, sp) banana flour as natural antioxidant source in Indonesian meatball production
}

\author{
*Suniati, F.R.T. and Purnomo, H. \\ Food Technology Department, Tourism Faculty, Ciputra University, Surabaya 60219, Indonesia
}

\author{
Article history: \\ Received: 14 November 2018 \\ Received in revised form: 24 \\ March 2019 \\ Accepted: 7 April 2019 \\ Available Online: 18 May \\ 2019
}

Keywords:

Goroho banana,

Banana flour,

Indonesian meatball,

Antioxidant

DOI:

https://doi.org/10.26656/fr.2017.3(6).302

\begin{abstract}
The aim of this study was to investigate the potentiality of Goroho (Musa acuminafe, sp) banana flour as a natural antioxidant in the production of Indonesian meatball. This study was carried out in two stages namely the first stage was banana flour preparation and the second stage was preparing the meatball using $10 \%$ tapioca flour, combination of $5 \%$ tapioca flour and 5\% banana flour and 10\% banana flour. The results of this study showed that $100 \%$ banana flour substitution had the highest DPPH value of $27.95 \pm 0.88 \%$ ) with phenol content of $29.31 \pm 6.74 \%$ and tannin content of $71.88 \pm 2.36 \%$. The organoleptic evaluation showed that the combination of 5\% tapioca flour and 5\% banana flour was the most favoured by the panellists. Meatball with a combination of 5\% tapioca flour and 5\% banana flour is recommended to be produced as functional Indonesian meatball.
\end{abstract}

\section{Introduction}

Goroho (Musa acuminafe, $s p$ ) is one of the banana varieties found in Manado (North Sulawesi). The fresh food is not consumed directly, but it is deep fried or steamed first before consumed. Therefore, most of Goroho banana is harvested before ripening. Usually, this banana is processed as banana chips and consumed with Roa fish sauce. According to local belief, Goroho banana could decrease the amount of blood sugar and therefore Goroho banana is consumed as a food supplement to control blood sugar.

Starch as a major component of raw banana could be found in the amount of $60-80 \mathrm{~g} / 100 \mathrm{~g}$ (dry basis) fruit flesh, and this amount is similar to starch content of maize and potato (Zhang et al., 2005). Menezes et al. (2011) reported that unripen fresh banana flour contained $56.24 \mathrm{~g} / 100 \mathrm{~g}$ which consist of $48.99 \mathrm{~g} / 100 \mathrm{~g}$ resistant starch, fructan $0.05 \mathrm{~g} / 100 \mathrm{~g}$, and fiber without resistant starch and fructan $7.2 \mathrm{~g} / 100 \mathrm{~g}$. The starch content of unripen fresh banana flour was $27.78 \mathrm{~g} / 100 \mathrm{~g}$, and soluble sugar was $1.81 \mathrm{~g} / 100 \mathrm{~g}$.

There are two varieties of this banana namely white and red Goroho banana and these fruits have been shown to contain high amounts of high antioxidant substances. Nurali et al. (2012) reported that the results of DPPH analysis of white Goroho banana had an antioxidant activity $13.34 \%$ with total phenol $0.05 \mathrm{mg} / 100 \mathrm{~g}$, vitamin C $69.25 \%$ and tannin $0.13 \%$. Furthermore, Kaempe et al. (2013) noted that Goroho banana contained phenolic, flavonoid and tannin compounds and from those three the highest amount was phenolic (162.41 $\mathrm{mg} / \mathrm{kg})$ followed by tannin $(35.97 \mathrm{mg} / \mathrm{kg})$ and flavonoid (4.39 $\mathrm{mg} / \mathrm{kg}$ ). It is possible that the presence of antioxidant substances in Goroho banana could lead to a decrease in the blood sugar level type 2 diabetic patients. Hardisson et al. (2001) reported that in fresh banana flesh contained phytosterol and glucoside sterol. Therefore, fresh banana flesh flour could be used as an antioxidant substance in food preparation.

One of the processed comminute meat products which are popular with the youth of Indonesia is a restructured beef ball or more famously known as beef "bakso". "Bakso" can be prepared from pork, chicken or fish also, and is found in the marketplaces throughout the cities and villages of Indonesia. This product is served deep-fried, barbequed or just steam/boiled "bakso" together with vegetables, noodles, fried/steam tofu filled with "bakso" batter or "bakso" in chicken or beef stock soup (Triatmojo, 1992; Rahardiyan, 2004; Purnomo and Rahardiyan, 2008). Therefore, Utami et al. (2007) noted "bakso" as one representative of Indonesian ethnic food.

"Bakso" is believed as good source of protein and Purnomo and Rahardiyan (2008) reported that "bakso" contained protein 13.38 to $14.44 \%$ and carbohydrate 8.02 to $25.86 \%$, while Huda et al. (2010) noted that Malaysian commercially prepared beef meatball contained 1.69 to $11.09 \%$ fat with ash content in the range of 1.76 to $3.40 \%$. Gok and Bor (2012) reported a 
positive effect of olive leaf extract, blueberry fruit extract and Zizyphusjujuba seed extract addition on color, chemical, microbiological and sensory properties of meatballs. Use of any extract can delay lipid oxidation and extend shelf-life. The highest scores for overall sensory quality was obtained for the meatballs having $1000 \mathrm{ppm}$ of blueberry fruit extract. However, there is no publication on the antioxidant activities found in "bakso" and therefore this study aimed to find out the potential of Goroho banana flour as a natural antioxidant in the production of Indonesian meatball.

\section{Materials and methods}

\subsection{Materials}

Goroho banana flour was prepared from unripe White Goroho banana (Musa acuminafe, sp.) and was bought from Manado. While topside beef fillet was obtained from a local butcher in Citraland Market.

\subsection{Preparation of Goroho banana flour}

Goroho banana obtained from Manado (North Sulawesi) were steamed for 5 mins then peeled to separate the peel and banana flesh. Banana flesh was sliced thinly, then dried in cabinet drier at $70 \pm 5^{\circ} \mathrm{C}$ for 8 hrs. After drying, the banana flesh was powdered and strained using a strainer of 80 mesh, then those samples are packed in aluminium foil pouches and stored at ambient temperature before laboratory analysis and used as substitute substance in meatball preparation.

\subsection{Preparation of meatball}

The preparation of meatball will follow the formula and flow chart as described by Rahardiyan (2004) with a slight modification i.e. finely ground meat was mixed thoroughly using a food processor with cooking salt, sodium tripolyphosphate, ice cubes, starch (Meatball A: $10 \%$ tapioca flour $+0 \%$ fresh banana flour; Meatball B: $5 \%$ tapioca flour $+5 \%$ fresh banana flour; and Meatball C: $0 \%$ tapioca flour $+10 \%$ fresh banana flour), and spices (fried onion, fried garlic, pepper). The meatball batter was then formed in ball size $(14 \mathrm{~g})$ and boiled in water at $100^{\circ} \mathrm{C}$ for 20 mins. After they were boiled, all samples were drained and packed in polyethylene pouches and stored at $4{ }^{\circ} \mathrm{C}$ before laboratory analysis.

\subsection{Experimental design}

This study was carried out in two stages. The first stage was the banana flour preparation and the second stage were to substitute the tapioca flour usually used as starch source with the Goroho banana flour in the meatball preparation. The experiments were conducted with two replications and the data obtained was statistically analysed.

\subsection{Parameters determination}

The parameters measured parameters include antioxidant activities (DPPH radical scavenging assay), total phenolic content, total tannin content and sensory evaluation as follows:

\subsubsection{Antioxidant activity (DPPH)}

The free radical scavenging activities of the extracts were determined by using 2, 2-Diphenyl-1picrylhydrazyl (DPPH) free radical scavenging modification method of Brand-Williams et al. (1995). DPPH in oxidized form gives a deep violet colour in methanol. An antioxidant compound donates the electron to DPPH thus causing its reduction and in reduced from its colour changes from deep violet to yellow. A fresh $0.002 \%$ solution of DPPH was prepared in methanol, and its absorbance was recorded at $517 \mathrm{~nm} .50 \mu \mathrm{L}$ of pure extracts were mixed with $3 \mathrm{~mL}$ solution of DPPH and allowed to stand in darkness for 15 mins. The absorbance was again recorded at $517 \mathrm{~nm}$.

\subsubsection{Total phenolic content}

The total phenolic content of all samples was determined by using Folin-Ciocalteu, modification of Odabasoglu et al. (2004). A standard gallic acid curve was constructed by preparing the dilutions of $(0.1,0.5$, $1.0,2.5$ and $5 \mathrm{mg} / \mathrm{mL}$ ) in methanol from standard 1 solution of gallic acid. $100 \mu \mathrm{L}$ of each of these dilutions were mixed with $500 \mu \mathrm{L}$ of water and then with $100 \mu \mathrm{L}$ of Folin-Ciocalteu reagent and allowed to stand for 6 minutes. Then, $1 \mathrm{~mL}$ of $7 \%$ sodium carbonate and 500 $\mu \mathrm{L}$ of distilled water was added to the reaction mixture. The absorbance was recorded after 90 mins at $750 \mathrm{~nm}$ using a spectrophotometer. The same procedure was repeated with the pure hot water extracts of all the three formulations. The total phenolic content of the samples was calculated as gallic acid equivalents (mg GAE/g). All the experiments were performed in triplicate.

\subsubsection{Total tannin content}

The tannin contents or Proanthocyanidin were determined following the method of Broadhurst and Jones (1978) with slight modification, using catechin as a reference compound. A volume of $400 \mu \mathrm{L}$ of the extract is added to $3 \mathrm{~mL}$ of a solution of vanillin (4\% in methanol) and $1.5 \mathrm{~mL}$ of concentrated hydrochloric acid. After 15 mins of incubation, the absorbance was read at $500 \mathrm{~nm}$. The condensed tannin was expressed as $\mathrm{g}$ E.Catechin.100g-1DM.

\subsubsection{Total flavonoid content}

Aluminium chloride complex forming assay was used to determine the total flavonoid content of the 
extracts, modification method of Chantiratikul et al. (2009). Quercetin was used as standard and flavonoid content was determined as quercetin equivalent. A calibration curve for quercetin was drawn for this purpose. From the standard 2 quercetin solution the dilutions of $(0.1, \quad 0.5, \quad 1.0, \quad 2.5$ and $5 \mathrm{mg} / \mathrm{mL})$ concentrations were prepared in methanol. $100 \mu \mathrm{L}$ of each of the quercetin dilution was mixed with $500 \mu \mathrm{L}$ of distilled water and then with $100 \mu \mathrm{L}$ of $5 \%$ sodium nitrate and allowed to stand for 6 mins. Then, $150 \mu \mathrm{L}$ of $10 \%$ aluminium chloride solution was added and allowed to stand for 5 mins after which $200 \mu \mathrm{L}$ solution of $1 \mathrm{M}$ sodium hydroxide was added sequentially. The absorbance of this reaction mixture was recorded at 510 $\mathrm{nm}$ on UV spectrophotometer. The same procedure was repeated with the extracts of samples and total flavonoid content was calculated as quercetin equivalents (mgQE/ $\mathrm{g})$. All the procedures were performed in triplicate.

\subsubsection{Sensory evaluation}

Sensory evaluation performed include colour, flavour, taste, texture and after taste. The analysis used was hedonic scale scoring with 5 level preference, $1=$ dislike very much, $2=$ dislike, $3=$ neither like nor dislike, $4=$ like, $5=$ like very much. Sensory analysis was done by randomly handing out 5 kinds of samples, with 5 treatment, each of which has been assigned a different code to 30 untrained panellists. Panellists were asked to provide an assignment of the sample according to the hedonic scale scoring (Meilgaard et al., 1999).

\section{Result and discussion}

The data in Table 1 showed that the addition of Goroho banana flour has no significant effect on moisture, ash, protein, lipid and crude fibre contents of meatballs.
The results showed that antioxidant activity of Goroho banana flour using DPPH method was $12.15 \pm 0.06 \%$. According to Kanopa et al. (2012), Goroho banana flour soaked with spices has a higher antioxidant content than control (soaked in aquadest). The content varies depending on the type of spices used. The following are the antioxidant content of Goroho banana flour which has been soaked in a solution of bay leaf extract, turmeric, clove, andaliman, galangal, nutmeg, lemongrass leaves, cinnamon, ginger, and white pepper in sequence: $73.09 \% ; 71.86 \% ; 71.24 \% ; 61.15 \%$; $52.83 \% ; 52.46 \% ; 52.40 \% ; 52.28 \% ; 46.86 \%$ and $46.74 \%$. This showed that Goroho banana flour extract absorbed the antioxidant content of spices, so the antioxidant content became higher when compared to the control, $45.01 \%$. In the study of Togolo et al. (2013), it was shown that Goroho banana flour which has been soaked in Kalamansi lemon extract solution increased the antioxidant activity. The antioxidant contents of Goroho banana flour extracts were $53.3 \% ; 72.7 \% ; 73.1 \%$ and $77.25 \%$ soaked in $25 \%, 50 \%, 75 \%$ and $100 \%$ Kalamansi lemon solution respectively. While the content of the control (soaked in aquadest) was $51.65 \%$. The results of this study showed that the antioxidant content of Goroho banana flour was lower compared to the previous studies. The increased antioxidant activity levels in previous studies compared to the current levels can be explained by the absence of soaking in this study. Based on the research by Nurali et al. (2012), white Goroho bananas had an antioxidant activity of $13.34 \%$. These results were comparable to the antioxidant activity of Goroho banana flour from this study, due to the use of the same type of banana.

The results (Table 2) showed that the addition of Goroho banana flour in meatballs preparation affected the antioxidant activity of the end product. With an increased percentage of Goroho banana flour, the

Table 1. Proximate contents of Goroho banana flour and meatball prepared using different concentration of tapioca flour and Goroho banana flour.

\begin{tabular}{lccccc}
\hline \multicolumn{1}{c}{ Sample } & Moisture (\%) & Ash (\%) & Lipid (\%) & Protein (\%) & Crude Fibre (\%) \\
\hline Goroho banana flour & $3.96 \pm 0.06$ & $3.14 \pm 0.01$ & $0.52 \pm 0.02$ & $2.55 \pm 0.06$ & $0.79 \pm 0.01$ \\
Meatball A & $73.60 \pm 0.66^{\mathrm{a}}$ & $2.60 \pm 0.34^{\mathrm{a}}$ & $0.85 \pm 0.33^{\mathrm{a}}$ & $16.30 \pm 1.41^{\mathrm{a}}$ & $0.26 \pm 0.01^{\mathrm{a}}$ \\
Meatball B & $73.60 \pm 1.13^{\mathrm{a}}$ & $2.67 \pm 0.14^{\mathrm{a}}$ & $1.18 \pm 0.20^{\mathrm{a}}$ & $15.86 \pm 0.56^{\mathrm{a}}$ & $0.26 \pm 0.03^{\mathrm{a}}$ \\
Meatball C & $73.39 \pm 1.29^{\mathrm{a}}$ & $2.23 \pm 0.14^{\mathrm{a}}$ & $1.62 \pm 0.43^{\mathrm{a}}$ & $17.31 \pm 0.39^{\mathrm{a}}$ & $0.23 \pm 0.01^{\mathrm{a}}$ \\
\hline
\end{tabular}

Different alphabet superscript within the same column shows significant difference at $p<0.05$.

Table 2. Antioxidant activity, total phenol, total tannin and total flavonoid of Goroho banana flour and meatball prepared using different concentration of tapioca flour and Goroho banana flour.

\begin{tabular}{lcccc}
\hline \multicolumn{1}{c}{ Sample } & DPPH $(\%)$ & Total Phenol $(\mathrm{mg} / 100 \mathrm{~g})$ & Total Tannin $(\mathrm{mg} / 100 \mathrm{~g})$ & Total Flavonoid $(\mathrm{mg} / 100 \mathrm{~g})$ \\
\hline Goroho banana flour & $12.15 \pm 0.06$ & $97.42 \pm 0.59$ & $159.70 \pm 2.83$ & $1.34 \pm 0.07$ \\
Meatball A & $12.94 \pm 1.52^{\mathrm{a}}$ & $28.54 \pm 6.83^{\mathrm{a}}$ & $46.07 \pm 3.53^{\mathrm{a}}$ & $0.07 \pm 0.06^{\mathrm{a}}$ \\
Meatball B & $16.08 \pm 3.31^{\mathrm{ab}}$ & $29.31 \pm 6.74^{\mathrm{a}}$ & $71.88 \pm 2.36^{\mathrm{b}}$ & $0.08 \pm 0.01^{\mathrm{a}}$ \\
Meatball C & $27.95 \pm 0.88^{\mathrm{c}}$ & $69.13 \pm 0.74^{\mathrm{b}}$ & $152.55 \pm 5.53^{\mathrm{c}}$ & $0.12 \pm 0.03^{\mathrm{a}}$ \\
\hline
\end{tabular}

Different alphabet superscript within the same column shows significant difference at $p<0.05$. 
antioxidant activity of meatballs increased. FernandezLopez et al. (2005) reported that the addition of antioxidant extract to the meatball could delay the lipids oxidation of meatballs in storage for 12 days. Delaying of the rancidity process indicates that existence of antioxidant activity. Tomović et al. (2017) also reported that natural antioxidants are added to fresh and processed meat products to delay, retard, or prevent lipid oxidation, retard the development of off-flavours (rancidity), improve colour stability, improve microbiological quality and extend shelf-life, without any damage to the sensory or nutritional properties. Based on research by Ilyasoglu (2014), adding rosehip seed flour as an antioxidant source to meatballs can increase the stability of antioxidant activity during storage.

The results showed that total phenol of Goroho banana flour was $97.42 \pm 0.59 \mathrm{mg} / 100 \mathrm{~g}$. Nurali et al. (2012) noted that the total phenol of Goroho banana flour is $0.05 \mathrm{mg} / 100 \mathrm{~g}$. According to Kaempe et al. (2013), the total phenol of Goroho banana flour is 162.41 $\mathrm{mg} / \mathrm{kg}$, equivalent to $16.24 \mathrm{mg} / 100 \mathrm{~g}$. The total phenol of Goroho banana flour was higher than the previous study, and the differences could be due to the area where Goroho banana are grown, and the environment in which the bananas were planted may also affect the chemical substance content of Goroho banana.

Kaempe et al. (2013) noted that Goroho banana contained phenolic, flavonoid and tannin antioxidant and from those three kinds of antioxidant substances the highest content was phenolic $(162.41 \mathrm{mg} / \mathrm{kg})$ followed by tannin $(35.97 \mathrm{mg} / \mathrm{kg})$ and flavonoid $(4.39 \mathrm{mg} / \mathrm{kg})$. Nurali et al. (2012) reported that total phenol of Goroho banana was $0.05 \mathrm{mg} / 100 \mathrm{~g}$, vitamin C $69.25 \%$, and tannin $0.13 \%$. Based on data in Table 2 , the difference in the addition of Goroho banana flour may result in a total difference in the meatballs phenol. With higher levels of Goroho banana flour, the total phenol content of the meatballs increased, and it is directly proportional to the increase in antioxidant activity of meatballs.

The results showed that total tannin of Goroho banana flour $159.70 \pm 2.83 \mathrm{mg} / 100 \mathrm{~g}$. According to Kaempe et al. (2013), total tannin of Goroho banana flour is $35.97 \mathrm{mg} / \mathrm{kg}$, equivalent to $3.6 \mathrm{mg} / 100 \mathrm{~g}$. Total tannin of Goroho banana flour was higher than in the previous study and this differences could be explained by the area where the Goroho bananas were planted as well as the surrounding environment which may affect the Goroho bananas chemical components. According to the data in Table 2, differences in the addition of Goroho banana flour may result in a difference in total tannin of meatballs. Increased levels of Goroho banana flour, resulted in an increase in the total tannins of meatballs.
This is directly proportional to the increase in antioxidant activity and total phenol in meatballs. Total tannin contributes to the increased antioxidant activity of meatballs.

The results showed that total flavonoid Goroho banana flour was $1.34 \pm 0.07 \mathrm{mg} / 100 \mathrm{~g}$. According to Kaempe et al. (2013), the total Goroho banana flavonoid is $4.39 \mathrm{mg} / \mathrm{kg}$, equivalent to $0.44 \mathrm{mg} / 100 \mathrm{~g}$. Total flavonoid content in Goroho banana flour found in this research is higher than the one reported in previous research. This difference could be due to the banana planting area or as a result of differences in the surrounding environment which may affect the chemical content of Goroho bananas. According to Aristyanti (2014), the content of soil components affects the content of flavonoids. The leaves of the tabat barito (Ficus deltoidea) plant found in TNGGP (Taman Nasional Gunung Gede Pangrango: Mount Gede Pangrango National Park) have a flavonoid content of $3.54 \%$. This level is higher than those found in Queen's Crater (TNGHS/ Taman Nasional Gunung Halimun Salak: Mount Halimun Salak National Park), which is $2.41 \%$. After further research, there were differences in the chemical content of the soil in both locations. Land in TNGGP have N-Total, $\mathrm{P}, \mathrm{K}, \mathrm{Ca}, \mathrm{S}$ available at $0.6 \%$, $197.10 \mathrm{ppm}, 240.35 \mathrm{ppm}, 25.23 \mathrm{me} / 100 \mathrm{~g}$, and 10.20 respectively. While the content in TNGHS respectively has $0.08 \%, 81.10 \mathrm{ppm}, 61.43 \mathrm{ppm}, 0.26 \mathrm{me} / 100 \mathrm{~g}$, and 7.65. According to the data in Table 2, differences in the addition of Goroho banana flour results in a total difference in flavonoid content of meatballs. With increased levels of Goroho banana flour, the total flavonoid of meatballs is higher. This is directly proportional to the increase in antioxidant activity, total phenol, and total tannins in meatballs, and hence the total flavonoid also contributes to an increased antioxidant activity in meatballs. The novelty of this research is to produce antioxidant-fortified meatball products from banana flour. Previous research (Ilyasoglu, 2014) already exists about meatballs enriched with rosehip flowers as a source of antioxidants, thereby increasing antioxidant stability during storage. The results of Fernandez-Lopez et al. (2005) showed that the addition of rosemary extract as a source of antioxidants to meatballs could slow the rancidity process during 12 days of storage. However, there has been no research on adding Goroho banana flour as a source of antioxidants to meatballs.

Based on data in Table 3, it is shown that from the aspect of appearance and colour parameters, most panellists favour the meatballs samples without substitution of Goroho banana flour (meatball A). Increased substitution of Goroho banana flour may decrease panellist's preference for the appearance and 
Table 3. The organoleptic score of meatballs prepared using tapioca flour substitute with Goroho banana flour at different concentration.

\begin{tabular}{ccccccc}
\hline Product & Appearance & Colour & Aroma & Taste & Texture & Overall acceptance \\
\hline Meatball A & $3.57 \pm 0.81^{\mathrm{a}}$ & $3.63 \pm 0.73^{\mathrm{a}}$ & $3.54 \pm 0.78^{\mathrm{a}}$ & $3.31 \pm 0.90^{\mathrm{ab}}$ & $3.74 \pm 0.78^{\mathrm{a}}$ & $3.77 \pm 0.65^{\mathrm{a}}$ \\
Meatball B & $3.11 \pm 0.72^{\mathrm{b}}$ & $3.29 \pm 0.62^{\mathrm{ab}}$ & $3.29 \pm 0.79^{\mathrm{a}}$ & $3.74 \pm 0.98^{\mathrm{a}}$ & $3.80 \pm 0.83^{\mathrm{a}}$ & $3.71 \pm 0.62^{\mathrm{a}}$ \\
Meatball C & $3.06 \pm 0.73^{\mathrm{b}}$ & $3.23 \pm 0.84^{\mathrm{b}}$ & $3.20 \pm 0.83^{\mathrm{a}}$ & $2.91 \pm 0.89^{\mathrm{b}}$ & $3.17 \pm 0.82^{\mathrm{b}}$ & $3.11 \pm 0.72^{\mathrm{b}}$ \\
\hline
\end{tabular}

Different alphabet superscript within the same column shows significant difference at $p<0.05$.

colour parameters of the meatballs. Substitution of Goroho banana flour caused the colour of meatballs to be darker, and the colour change occurs possibly due to Maillard reaction during the heating process. According to Martin et al. (2001), Maillard reaction is a reaction that occurs between reducing sugars and amino acids at heating temperatures. The Maillard reaction produces a brown polymer known as melanoidin.

\section{Conclusion}

Based on the results of this study it can be concluded that the best treatment based on proximate analysis, antioxidant activity, total phenol, total tannin, total flavonoid, and the organoleptic scores were meatballs substituted with 5\% Goroho banana flour. Therefore, this innovative meatball product has the potential to be developed commercially although socialization to the consumers is needed to choose these enriched meatballs with natural antioxidants which might be beneficial for consumer's health.

\section{Acknowledgement}

The authors would like to express their sincere gratitude to the Rector and Research Council Chairman of Ciputra University, Surabaya for their support and funding this research activity.

\section{References}

Aristyanti, D. (2014). Pengaruh Kadar Kimia Tanah terhadap Kandungan Flavonoid Daun Tabat Barito (Ficus deltoidea Jack). Indonesia, Bogor: Institute Pertanian, MSc. Thesis [In Bahasa Indonesia].

Boekoel, M.A.J.S. (2006). Formation of flavour compounds in the Maillard reaction. Biotechnology Advances, 24(2), 230-233. https://doi.org/10.1016/ j.biotechadv.2005.11.004

Brand-Williams, W., Cuvelier, M.E. and Berset, C.L.W.T. (1995). Use of a free radical method to evaluate antioxidant activity. LWT-Food Science and Technology, 28(1), 25-30. https://doi.org/10.1016/ S0023-6438(95)80008-5

Broadhurst, R.B. and Jones, W.T. (1978). Analysis of condensed tannins using acidified vanillin. Journal of the Science of Food and Agriculture, 29(9), 788794. https://doi.org/10.1016/S0023-6438(95)80008-5
Chantiratikul, P., Meechai, P. and Nakbanpotecc, W. (2009). Antioxidant activities and phenolic contents of extracts from Salvinia molesta and Eichornia crassipes. Research Journal of Biological Sciences, 4(10), 1113-1117.

Fernandez-Lopez, J., Zhi, N., Aleson-Carbonell, L., Perez-Alvarez, and Kuri, V. (2005). Antioxidant and antibacterial activities of natural extracts: application in beef meatballs. Meat Science, 69(3), 371-380. https://doi.org/10.1016/j.meatsci.2004.08.004

Gok, V. and Bor, Y. (2012). Effect of olive leaf, blueberry and Zizyphus jujuba extracts on the quality and shelf life of meatball during storage. Journal of Food, Agriculture and Environment, 10(2), 190-195.

Hardisson, A., Rubio, C., Baez, A., Martin, M., Alvarez, R. and Diaz, E. (2001). Mineral composition of the banana (Musa acuminate) from the island of Tenerife. Journal of Food Chemistry, 73(2), 153161. https://doi.org/10.1016/S0308-8146(00)00252-1

Huda, N., Shen, Y.H., Huey, Y.L., Ahmad, R. and Mardiah, A. (2010). Evaluation of PhysicoChemical Properties of Malaysian Commercial Beef Meatballs. American Journal of Food Technology, 5 (1), 13-21. https://doi.org/10.3923/ajft.2010.13.21

Ilyasoglu, H. (2014). Antioxidant effect of rosehip seed powder in raw and cooked meatballs during refrigerated storage. Turkish Journal of Veterinary and Animal Sciences, 38, 73-76. https:// doi.org/10.3906/vet-1301-39

Kaempe, H.S., Suryanto, E. and Kawengian, S.E.S. (2013). Potensi ekstrak fenolik buah pisang goroho (Musa spp.) terhadap gula darah tikus putih (Rattus norvegicus). Chemistry Progress, 6, 6-9. [In Bahasa Indonesia].

Kanopa, I.U., Momuat, L.I. and Suryanto, E. (2012). Aktivitas Antioksidan Tepung Pisang Goroho (Musa spp) yang Direndam dengan Beberapa RempahRempah/ Jurnal MIPA Unsrat Online, 1(1), 29-32. [In Bahasa Indonesia]. Retrieved from https:// media.neliti.com/media/publications/116509-IDaktivitas-antioksidan-tepung-pisang-goro.pdf

Martin, S.F.S., Jongen, W.M.F. and Boekel, M.A.J.S. (2001). A review of Maillard reaction in food and implications to kinetic modelling. Trends in Food Science and Technology, 11, 364-373. https:// 
doi.org/10.1016/S0924-2244(01)00022-X

Meilgaard, Morten, Civille, G.V. and Carr, B.T. (1999). Sensory Evaluation Techniques. $3^{\text {rd }}$ ed. Boca Raton, Florida: CRC-Press. https:// doi.org/10.1201/9781439832271

Menezes, E.W., Tadini, C.C., Tribess, T.B., Zuleta, A., Binaghi, J., Pak, N., Vera, G., Dan, M.C.T., Bertolini, A.C., Cordenunsi, B.R. and Lajolo, F.M. (2011). Chemical Composition and Nutritional Value of Unripe Banana Flour (Musa acuminate, var. Nanicao). Journal of Plants Food Human Nutrition, 66(3), 231-237. https://doi.org/10.1007/ s11130-011-0238-0

Nurali, E.J.N., Djarkasi, G.S.S., Sumual, M.F.S. and Lalujan, E.L. (2012). The Potential of Goroho Plantain as a Source of Functional Food. Final Report of Tropical Plant Curriculum Project. America: Texas A\&M AgriLife. Retrieved from website: https://pingpdf.com/pdf-the-potential-ofgoroho-plantain-as-a-source-of-seafast-ipb.html

Odabasoglu, F., Aslan, A., Cakir, A., Suleyman, H., Karagoz, Y., Halici, M. and Bayir, Y. (2004). Comparison of antioxidant activity and phenolic content of three lichen species. Phytotherapy Research, 18(11), 938-941. https://doi.org/10.1002/ ptr. 1488

Purnomo, H. and Rahardiyan, D. (2008). Review Article Indonesian Traditional Meatball. International Food Research Journal, 15(2), 101-108.

Rahardiyan, D. (2004). Bakso (Traditional Indonesian Meatball) Properties with Postmortem Condition and Frozen Storage. USA: Louisiana State University, MSc. Thesis.

Togolo, E., Suryanto, E. and Sangi, M.E. (2013). Aktivitas Antioksidan dari Tepung Pisang Goroho yang Direndam dengan Lemon Kalamansi. Jurnal MIPA Unsrat Online, 2(2), 105-108. [In Bahasa Indonesia]. Retrieved from https://media.neliti.com/ media/publications/116257-ID-aktivitas-antioksidandari-tepung-pisang.pdf.

Tomović, V., Jokanović, M., Šojić, B., Škaljac, S. and Ivić, M. (2017). Plant as natural antioxidant for meat products. IOP Conference Series 85: Earth and Environmental Science. IOP Publishing. https:// doi.org/10.1088/1755-1315/85/1/012030

Triatmojo, S. (1992). Pengaruh penggantian daging sapi dengan daging kerbau, ayam, dan kelinci pada komposisi dan kualitas fisik bakso (The effects of beef substitution with bull, chicken and rabbit meat in the composition and physical qualities of bakso). Buletin Peternakan, 16, 63-70. https:// doi.org/10.21059/buletinpeternak.v16i1.1740
Utami, H.D., Rauniyar, G., Bailey, W.C., Morris, S. and Purnomo, H. (2007). Marketing strategy as food processor response towards Malang meatballs. Journal of Food Products Marketing, 13(4), 79-97. https://doi.org/10.1300/J038v13n04_05

Zhang, P., Whistler, R.L., Bemiller, J.N. and Hamaker, B.R. (2005). Banana starch: production, physicochemical properties, and digestibility - a review. Carbohydrate Polymers, 59(4), 443-458. https://doi.org/10.1016/j.carbpol.2004.10.014 